\title{
The non-competitive metabotropic glutamate receptor-1 antagonist CPCCOEt inhibits the in vitro growth of human melanoma
}

\author{
HELGA SUSANNE HAAS ${ }^{1}$, ROSWITHA PFRAGNER ${ }^{1}$, VERONIKA SIEGL ${ }^{1}$, ELISABETH INGOLIC ${ }^{2}$, \\ ELFGARD HEINTZ ${ }^{1}$, ELISABETH SCHRAML ${ }^{1}$ and KONRAD SCHAUENSTEIN ${ }^{1}$
}

\begin{abstract}
${ }^{1}$ Department of Pathophysiology, Center of Molecular Medicine, Medical University Graz, Heinrichstrasse 31A, 8010 Graz;
${ }^{2}$ Research Institute for Electron Microscopy and Fine Structure Research, University of Technology Graz,
\end{abstract}

Steyrergasse 17, 8010 Graz, Austria

Received January 16, 2007; Accepted February 22, 2007

\begin{abstract}
Five decades ago, the dicarboxylic amino acid glutamate became recognized as the major excitatory neurotransmitter in the central nervous system. In recent years, the expression of glutamate receptors was detected also in peripheral, non-neuronal tissues. Furthermore, it was found that glutamate stimulated the proliferation and migration of several peripheral tumor cells, and that glutamate receptor antagonists limited tumor growth. Most of these studies, however, used broad spectrum compounds and/or groupspecific antagonists. Here we report that a selective, noncompetitive metabotropic glutamate receptor-1 antagonist, CPCCOEt (7-hydroxyiminocyclopropan[b]chromen-1acarboxylic acid ethyl ester), significantly inhibited the proliferation and modified the morphology of two human melanoma cell lines. These effects were independent of the external glutamate level in the culture medium. In addition, CPCCOEt significantly enhanced the tumoricidal effects of cytostatic drugs. Thus, selective non-competitive metabotropic glutamate receptor antagonists may be used alone and/or with the synergistic effects of chemotherapy, thus enhancing existing therapies of melanoma and possibly other malignancies.
\end{abstract}

\section{Introduction}

Glutamate is the predominant excitatory neurotransmitter in the central nervous system and stimulates receptors which are divided into ionotropic (ligand-gated ion channels) and

Correspondence to: Dr Helga Susanne Haas, Department of Pathophysiology, Center of Molecular Medicine, Medical University Graz, Heinrichstrasse 31A, 8010 Graz, Austria

E-mail: helga.haas@meduni-graz.at

Key words: metabotropic glutamate receptors, non-competitive metabotropic glutamate receptor antagonist, human melanoma, cell proliferation, tumor growth metabotropic (G-protein-coupled) glutamate receptors (1-3). Until recently, glutamate signalling was thought to be restricted to the central nervous system, and glutamate has been implicated in the pathogenesis of human neurological and neurodegenerative psychiatric disorders, as well as traumatic brain injury $(4,5)$. More recently, however, it has become apparent that also various peripheral, non-neuronal cells express different types of glutamate receptors (6). Accordingly, increasing attention has been directed to the role of glutamate signal transduction in these tissues. Triggered by the observation that glutamate regulates proliferation, migration and survival of neuronal progenitors $(7,8)$, Rzeski et al (9) reported that glutamate also stimulates the proliferation and migration of tumor cells, and ionotropic glutamate receptor antagonists were found to inhibit the proliferation of several tumor cell lines, such as colon adenocarcinoma, breast carcinoma, thyroid carcinoma, lung carcinoma, astrocytoma and neuroblastoma. Furthermore, this study showed that the same ionotropic glutamate receptor antagonists enhanced the tumoricidal effects of cytostatic drugs (cyclophosphamide, cisplatin, thiotepa, and vinblastin). In line with these data, our group observed that glutamate as well as ionotropic glutamate receptor reactive drugs differentially modulated growth and morphology of human histiocytic lymphomaderived U937 cells (10). Results from another group indicated that overexpression of the glutamate receptor subunit NMDAR1 (N-methyl-D-aspartate) significantly correlated with tumor size, lymph node metastasis and cancer stage of oral squamous cell carcinoma (11).

Recent microarray data revealed that many G-proteincoupled receptors (GPCRs) including metabotropic glutamate receptors (mGluRs), are implicated in the tumorigenesis and metastasis of human cancers (12). Metabotropic glutamate receptor-4 expression was detected in colorectal carcinoma $(68 \%)$, but also in $63 \%$ of malignant melanoma, and overexpression was associated with recurrence and poor disease-free survival (13). mGluR1 mRNA expression was found in human MG-63 osteoblast-like osteosarcoma cells (14) as well as in Jurkat T cells (15), and upregulation of mGluR 1 was detected in metastatic melanoma (12). In addition, duplex RT-PCR analysis indicated that the mGluR1 
subunit was expressed in 7 of 19 melanoma samples, but not in two benign nevi (16). Western blot analysis likewise showed that mGluR1 was expressed in 12 of 18 human melanoma cell lines, but not in normal human melanocytes (16). The same group characterized a mouse melanoma model, which has implicated the ectopic expression of mGluR1 in melanogenesis and metastasis $(16,17)$. In continuation of these experiments Marín et al (18) showed in mouse melanoma cell lines that stimulation of mGluR 1 results in inositol triphosphate $\left(\mathrm{IP}_{3}\right)$ accumulation and extracellular-regulated kinases 1 and 2 (ERK 1/2) activation, which both could be inhibited by pretreatment of the tumor cells with a mGluR1 subtype-specific competitive antagonist LY367385.

Based on these findings, we investigated the effect of a selective non-competitive mGluR1 antagonist CPCCOEt (7hydroxyiminocyclopropan[b]chromen-1a-carboxylic acid ethyl ester) on the growth and morphology of two human melanoma cell lines (Human Bowes melanoma, HBMC; n15006 melanoma), which have been shown to stably express the mGluR1 subunit [16]. Litschig et al (19) were the first to describe this negative allosteric modulator and its specific binding site within the transmembrane heptahelical domain of human mGluR1. In addition, we also addressed the question whether combining this mGluR1 antagonist with established chemotherapeutic drugs (20-22) would enhance the cytostatic effect.

\section{Materials and methods}

Reagents. CPCCOEt was obtained from Sigma-Aldrich, Austria. Docetaxel was purchased from Fluka Riedel-de Haën, Switzerland. Cell culture vessels were obtained from Sarstedt (Wiener Neudorf, Austria). Culture media and supplements were obtained from Cambrex Bio Science (Verviers, Belgium) and PAA Laboratories (Linz, Austria).

Cell culture. Human Bowes melanoma cells (HBMC) (ATCC no. CRL-9607) were kindly provided by Dr Barbara Kofler, Department of Pediatrics, General Hospital Salzburg, Austria. The melanoma cell line n15006 was a gift from Dr Suzie Chen, Susan Lehman Cullman Laboratory for Cancer Research, Department of Chemical Biology, Ernest Mario School of Pharmacy, Rutgers University, Piscataway, NJ, USA. Human skin fibroblasts were used as non-malignant proliferating cells and obtained by outgrowth technique from a skin explant. Cells were cultured in normal Eagle's minimum essential medium (EMEM) (Cambrex Bio Science), supplemented with $10 \%$ fetal bovine serum (FBS) (PAA Laboratories), $100 \mathrm{IU}$ penicillin, and $100 \mu \mathrm{g} / \mathrm{ml}$ streptomycin (PAA Laboratories). For the experiments the cells were cultured without antibiotics. The optimal cell density was evaluated in preliminary tests. For glutamate starvation culture conditions, cells were cultivated in EMEM without glutamate, supplemented with $10 \%$ FBS. Cells were cultured at an initial cell number of $1 \times 10^{5}$ cells $/ \mathrm{ml}$ at $37^{\circ} \mathrm{C}$ in a humidified atmosphere containing $5 \% \mathrm{CO}_{2}$. For experiments, cells were transferred in microplates ( 24 wells, flat bottom) (Sarstedt). After $24 \mathrm{~h}$, medium was changed (day 0) and the cells were exposed either to CPCCOEt (1-200 $\mu \mathrm{M})$ alone, or docetaxel (5-10 ng/ml) (10 nM=8.08 ng/ml) (Fluka Riedel-de Haën) alone, and to $200 \mu \mathrm{M}$ of CPCCOEt together with $5-10 \mathrm{ng} / \mathrm{ml}$ docetaxel for 3 days (day 1 , day 2, day 3 in Figs.). CPCCOEt was diluted in dimethylsulfoxide (DMSO) (Sigma-Aldrich, Austria). Docetaxel was first diluted in DMSO and then further diluted in Hanks' balanced salt solution (HBSS) (Cambrex Bio Science). Compared to the culture medium, DMSO and HBSS per se did not appreciably modify cell growth. For cell counting the adherent cells were trypsinized with $0.25 \%$ trypsin diluted $1: 1$ in calciummagnesium-free phosphate-buffered saline (CMF-PBS) (both Cambrex Bio Science) for $6 \mathrm{~min}$. Cell counting was performed by the CASY $-1{ }^{\circledR}$ cell counter and analyser (Schärfe, Reutlingen, Germany).

WST-1 assay. The WST-1 assay is a test for cell viability and proliferation (Roche Diagnostics GmbH, Vienna, Austria) based on the cleavage of the tetrazolium salt WST-1 to formazan by mitochondrial dehydrogenase. Quantification of the formazan dye was performed by OD measurements at $450 / 650 \mathrm{~nm}$ by an ELISA reader (Molecular Devices Corporation, Sunnyvale, CA). The WST-1 assay was routinely performed together with determination of cell counts. Cells were transferred into 96-well microplates (Sarstedt, flat bottom) in a final volume of $100 \mu \mathrm{l} /$ well, to which cell proliferation reagent WST-1 (10 $\mu 1 /$ well) was added. The appropriate incubation time with the cell proliferation reagent WST-1 was determined to be 45 min for both melanoma cell lines. Cells were incubated at $37^{\circ} \mathrm{C}$ in a humidified atmosphere containing $5 \% \mathrm{CO}_{2}$ and shaken thoroughly for $5 \mathrm{~min}$ on a shaker before measurement.

Scanning electron microscopy. Cells were cultured as described above and cell pellets were fixed with $3 \%$ glutaraldehyde (Sigma-Aldrich, Germany) in cacodylate buffer (Sigma-Aldrich, Germany) (0.1 M, pH 6.8-7.2) for $24 \mathrm{~h}$ at $4^{\circ} \mathrm{C}$ and processed for scanning electron microscopy by routine methods.

Statistical analysis. Statistical analysis was performed using the one sided Student's t-test. $\mathrm{P}$ values $\leq 0.05$ were considered significant. All experimental results were expressed as mean values \pm SEM.

\section{Results}

Effects of CPCCOEt on growth and morphology of HBMC and 15006 melanoma cells cultured in media with glutamate or under glutamate starvation. Compared to controls, a 3-day treatment with $200 \mu \mathrm{M}$ of CPCCOEt significantly attenuated cell proliferation of both HBMC and n15006 melanoma cells cultured in normal EMEM (Fig. 1a). This effect started at day 2, was less pronounced at $100 \mu \mathrm{M}$ of CPCCOEt and declined at $50 \mu \mathrm{M}$ (data not shown). In the WST-1 assay a decrease of mitochondrial dehydrogenase activity was observed during the whole period of treatment (Fig. 1b and c). Since CPCCOEt exerts its effect via binding within the receptor transmembrane heptahelical domain, which is topographically distinct from the binding site of the endogenous ligand, glutamate, we also examined the effect of CPCCOEt 


\section{$\mathbf{a}$}
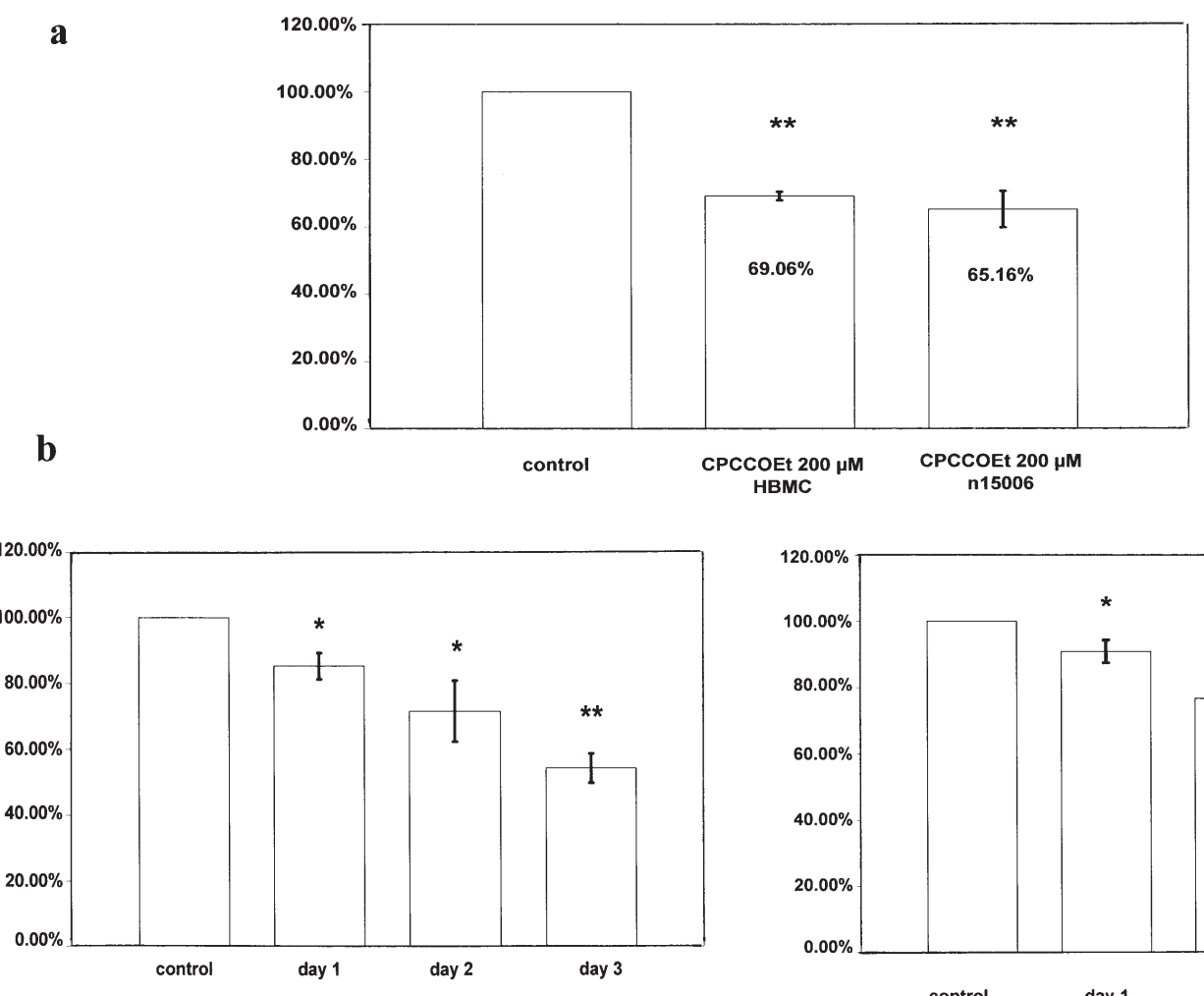

\section{HBMC}

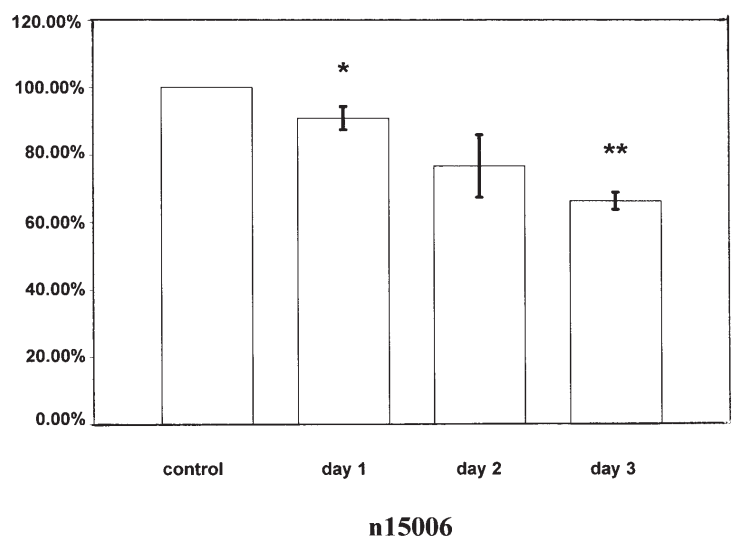

Figure 1. Modulatory effects of a 3-day treatment with CPCCOEt on proliferation and mitochondrial activity of human melanoma cells (HBMC, n15006) cultured in normal EMEM. (a) CPCCOEt $(200 \mu \mathrm{M})$ significantly decreased cell growth of both cell lines $\left(^{* *} \mathrm{p} \leq 0.01\right)$. The bar diagrams illustrate overall effects on cell proliferation. (b) CPCCOEt $(200 \mu \mathrm{M})$ significantly decreased the enzymatic activity of mitochondrial dehydrogenase of HBMC cells in the WST-1 assay $\left({ }^{*} \mathrm{p}<0.05 ;{ }^{* *} \mathrm{p} \leq 0.01\right)$. Three mean values derived from 6 samples each were compared. (c) CPCCOEt $(200 \mu \mathrm{M})$ likewise significantly decreased the enzymatic activity of mitochondrial dehydrogenase of $n 15006$ cells in the WST-1 assay $\left({ }^{*} \mathrm{p}<0.05 ;{ }^{* *} \mathrm{p} \leq 0.01\right)$. Three mean values derived from 6 samples each were compared. Error bars represent SEM. All experiments were performed in triplicate.

a

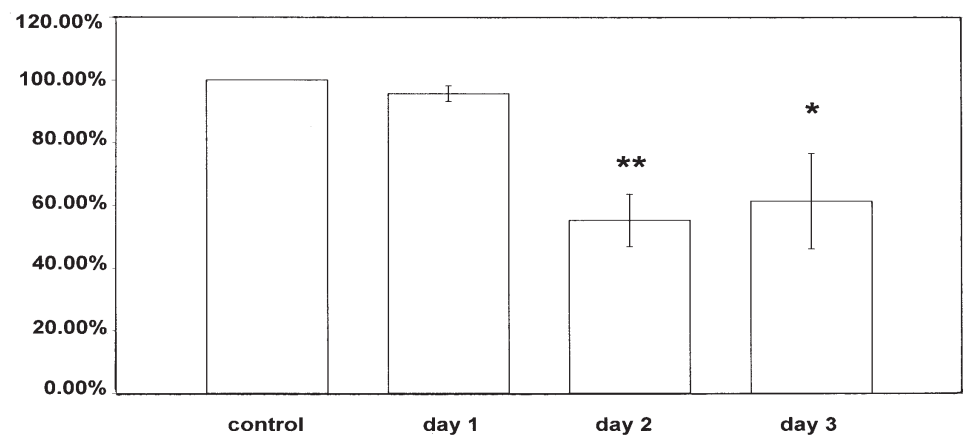

HBMC

b

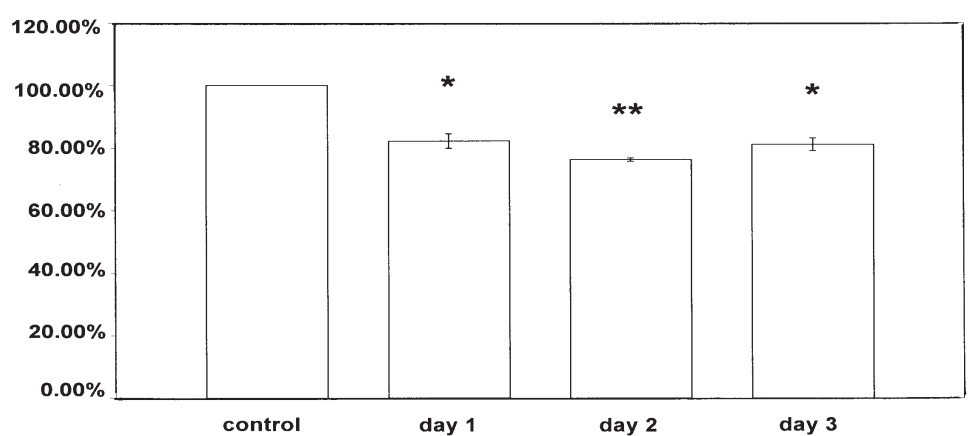

n15006

Figure 2. Modulatory effects of a 3-day treatment with CPCCOEt on mitochondrial activity of human melanoma cells (HBMC, n15006) cultured in glutamate-free EMEM supplemented with 10\% FBS. (a) CPCCOEt $(200 \mu \mathrm{M})$ significantly decreased the enzymatic activity of mitochondrial dehydrogenase of HBMC cells in the WST-1 assay ( $\left.{ }^{*} \mathrm{p}<0.05 ;{ }^{* *} \mathrm{p} \leq 0.01\right)$. Three mean values derived from 6 samples each were compared. (b) CPCCOEt (200 $\left.\mu \mathrm{M}\right)$ likewise significantly decreased the enzymatic activity of mitochondrial dehydrogenase of n15006 cells in the WST- 1 assay $\left({ }^{*} \mathrm{p}<0.05 ;{ }^{* *} \mathrm{p}<0.01\right)$. Three mean values derived from 6 samples each were compared. Error bars represent SEM. All experiments were performed in triplicate. 


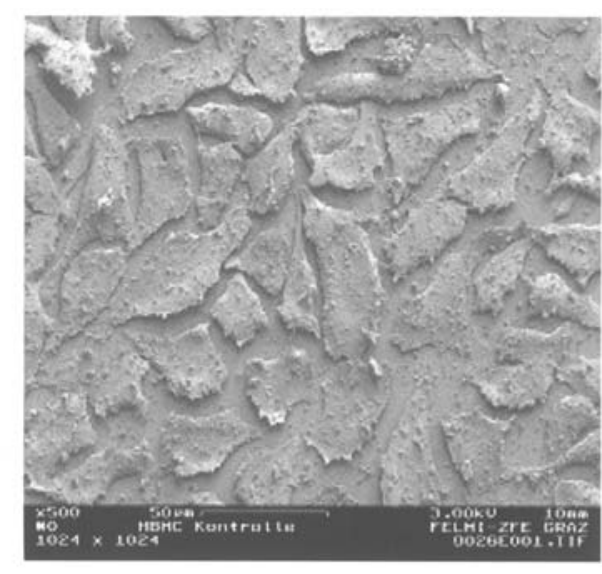

control

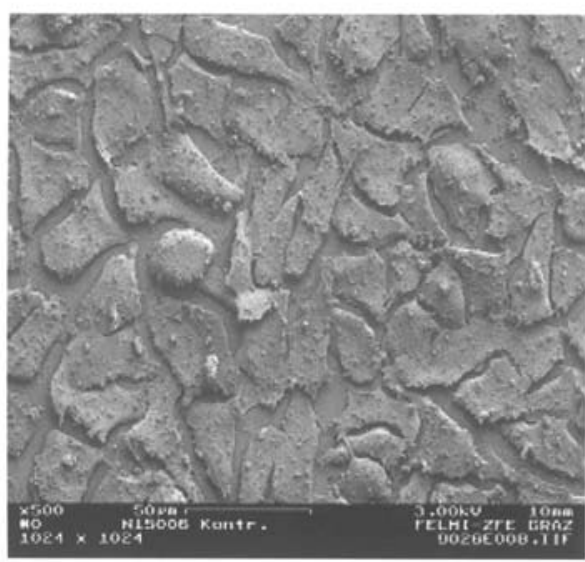

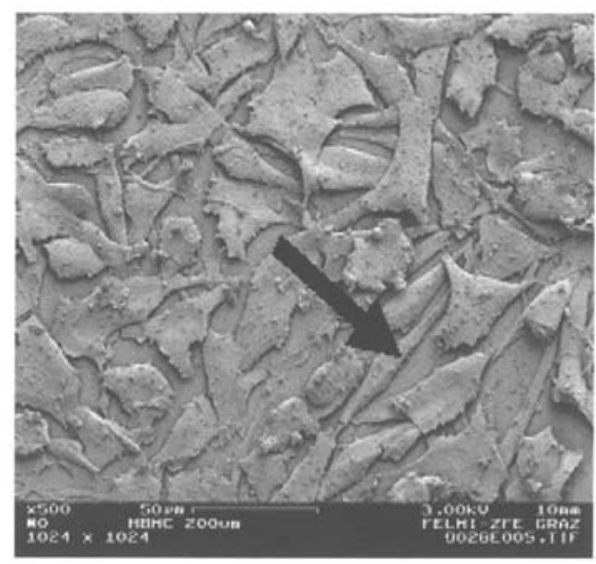

$200 \mu \mathrm{M} \mathrm{CPCCOEt}$

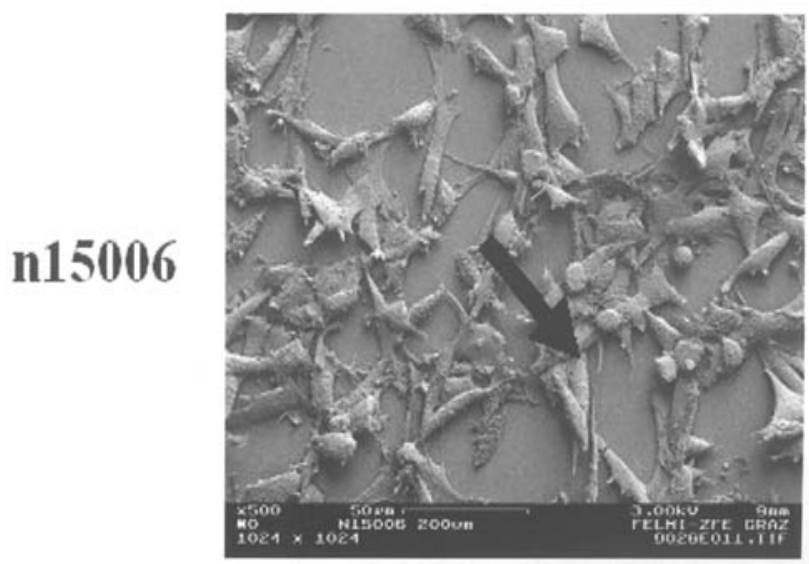

Figure 3. Scanning electron micrographs of HBMC and n15006 cells after treatment with CPCCOEt. Following administration of $200 \mu \mathrm{M}$ of CPCCOEt, HBMC as well as n15006 melanoma cells appeared to be more spindle-shaped (arrow). Bar, $50 \mu \mathrm{m}$.

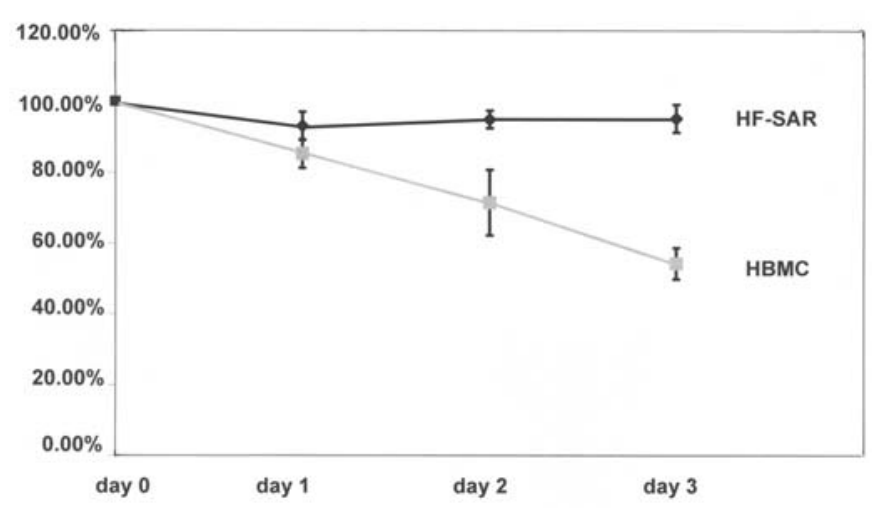

Figure 4. Effect of CPCCOEt on mitochondrial activity of human skin fibroblasts (HF-SAR) as non-malignant proliferating cells. In the WST-1 assay $200 \mu \mathrm{M}$ of CPCCOEt did not affect the enzymatic activity of mitochondrial dehydrogenase of HF-SAR cells, but again decreased the enzymatic activity of HBMC melanoma cells.

on melanoma cells cultured under glutamate starvation. To minimize the glutamate content, cells were cultured in a glutamate-free medium supplemented with $10 \%$ FBS. CPCCOEt likewise decreased cell growth at the same concentrations with the maximal effect observed at $200 \mu \mathrm{M}$ (not shown). WST-1 activity was also decreased in both cell lines, whereby the greatest decline was seen at day 2 (Fig. 2a and $b$ ). Interestingly, the competitive mGluR 1 antagonist (RS)-1-aminoindan-1,5-dicarboxylic acid (AIDA), as well as the agonists (1S,3R-)1-aminocyclopentane-1,3-dicarboxylic acid (ACPD) and glutamate per se did not affect cell proliferation of both cell lines (not shown). To examine possible morphological changes, scanning electron microscopy was performed. HBMC as well as n15006 melanoma cells appeared to be more spindle-shaped after treatment with $200 \mu \mathrm{M}$ of CPCCOEt, which may indicate a loss of adherence (Fig. 3). Human skin fibroblasts (HF-SAR) as non-malignant proliferating cells served as controls, and WST-1 activity was compared with melanoma (HBMC) cells treated with $200 \mu \mathrm{M}$ of CPCCOEt. CPCCOEt did not affect mitochondrial activity of HF-SAR cells, but again decreased the enzymatic activity of HBMC melanoma cells (Fig. 4).

CPCCOEt enhanced the tumoricidal effects of the cytostatic drug docetaxel. HBMC melanoma cells were subjected to treatment with either CPCCOEt, docetaxel alone, or CPCCOEt in combination with docetaxel for 3 days. CPCCOEt $(200 \mu \mathrm{M})$ as well as docetaxel $(10 \mathrm{ng} / \mathrm{ml})$ similarly inhibited cell proliferation. This effect was enhanced in cells treated with 
a

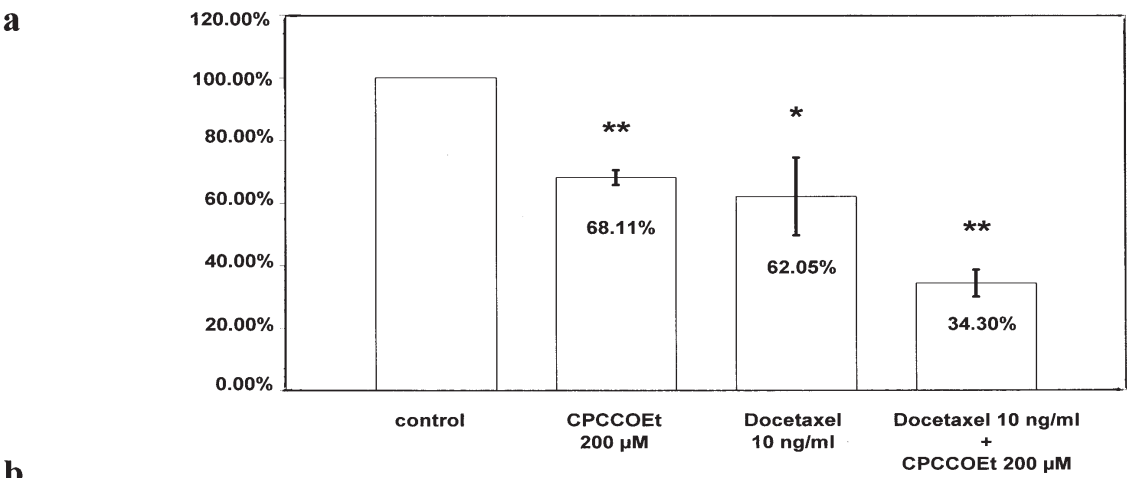

b

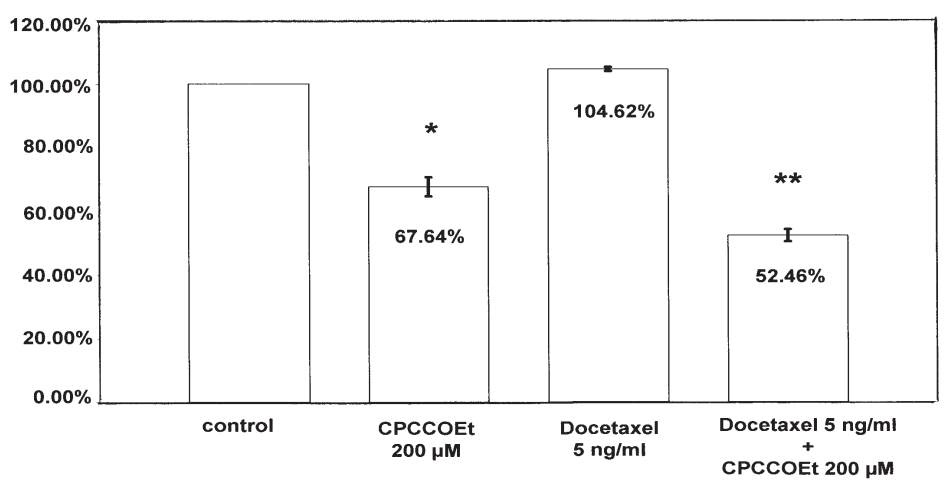

Figure 5. Effect of a 3-day treatment with CPCCOEt, docetaxel alone, or CPCCOEt in combination with docetaxel on HBMC cells. (a) CPCCOEt (200 $\mu \mathrm{M}$ ) as well as $10 \mathrm{ng} / \mathrm{ml}$ of docetaxel alone inhibited cell proliferation. Treatment with both CPCCOEt and docetaxel resulted in a clearly more pronounced effect in comparison with either treatment alone $\left({ }^{*} \mathrm{p}<0.05 ;{ }^{* *} \mathrm{p} \leq 0.01\right)$. (b) Administration of $5 \mathrm{ng} / \mathrm{ml}$ of docetaxel did not affect cell proliferation. In combination with $200 \mu \mathrm{M}$ of CPCCOEt a strong synergistic cytostatic effect was observed as compared to treatment with CPCCOEt alone $\left({ }^{*} \mathrm{p}<0.05 ;{ }^{* *} \mathrm{p} \leq 0.01\right)$. The bar diagrams illustrate overall effects on cell proliferation. Error bars represent SEM. Experiments were performed in triplicate.

both CPCCOEt and docetaxel (Fig. 5a). Administration of $5 \mathrm{ng} / \mathrm{ml}$ of docetaxel did not affect cell proliferation. However, in combination with $200 \mu \mathrm{M}$ of CPCCOEt a strong synergistic cytostatic effect was observed as compared to treatment with CPCCOEt alone (Fig. 5b). Similar effects were observed with WST-1 activity (not shown).

\section{Discussion}

It has been established that ionotropic glutamate receptor antagonists limit tumor growth in peripheral tissues and enhance the tumoricidal effects of cytostatic drugs (9). In line with this, our group observed that the competitive AMPA ( $\alpha$ amino-3-hydroxy-5-methylisoxazole-4-propionic acid)/ kainate receptor antagonist CNQX (6-cyano-7-nitroquinoxaline-2,3-dione) significantly decreased growth and altered morphology of the human histiocytic lymphoma cell line U937 (10). Furthermore, the mGluR1 subtype-specific competitive antagonist LY367385 inhibited the agonistinduced $\mathrm{IP}_{3}$ accumulation and ERK $1 / 2$ activation in melanoma cells (18). In this study we showed that the selective non-competitive mGluR1 antagonist CPCCOEt significantly, dose-dependently, and reversibly inhibited the growth of two human melanoma cell lines. Presently, we do not know the mechanisms and signal cascades underlying this effect. TUNEL analysis has provided no results up to now, indicating that apoptosis-associated DNA strand breaks do not occur. This is in line with observations by others, who reported that human melanoma cell lines per se are very resistant to apoptosis (23). Furthermore, the effect appeared to be independent of external calcium, since culturing the cells in a special calcium-magnesium-free medium resulted in the same inhibition of tumor growth (not shown). However, as mentioned above, ERK1/2 activation may play a role (18) that needs to be investigated in future experiments.

Scanning electron microscopy revealed a more spindle morphology of melanoma cells after treatment with CPCCOEt. At present, the significance of this result is still obscure. In 1986, Xiang and Kimura (24) reported that B16 melanoma cells assumed spindle morphology after a shift from Eagle's Hanks' medium with $10 \%$ newborn calf serum to Dulbecco's modified Eagle's medium with $10 \%$ fetal bovine serum. These morphological changes were characteristic of established criteria of melanoma differentiation, and alterations in the differentiation state had profound effects on metastatic potential. Overexpression of the mGluR 1 subunit was recently described in metastatic melanoma (12). Studies are underway to examine whether metabotropic glutamate receptor antagonists, in particular CPCCOEt, interfere with in vitro migration and in vivo metastasis of melanoma cells.

Finally, we observed that the combined administration of CPCCOEt and an established chemotherapeutic drug (docetaxel) resulted in a stronger cytostatic effect than either treatment alone. This was in line with the data of Rzeski, who reported that NMDA and AMPA antagonists enhanced the tumoricidal effects of cytostatic drugs (cyclophosphamide, cisplatin, thiotepa, and vinblastin) in vitro (9). In general, selective allosteric modulators of mGluRs have a promising 
therapeutic potential. Firstly, they act either as positive or negative modulators of the respective receptor without affecting the affinity or efficacy of the orthosteric ligand (25). Secondly, these compounds may improve the selectivity for individual mGluRs as well as enhance the scope for chemical tractability (26). In this direction, a new, promising, selective non-competitive mGluR1 antagonist, YM-298198, is now available, which is water soluble, whose binding site is close to the CPCCOEt allosteric site and which was shown to be highly active in vivo even with oral administration to exert an analgesic effect in streptozotocin-induced hyperalgesic mice (27). Recently, the group of Namkoong (28) suggested that the interference at specific points within GluR1 signal transduction should inhibit melanoma cell proliferation. The results of our study support this idea and may provide new concepts for cancer research and therapy.

\section{Acknowledgements}

This research was supported by the Austrian Cancer Aid/Styria (project no. 06/2004).

\section{References}

1. Ozawa S, Kamiya $\mathrm{H}$ and Tsuzuki K: Glutamate receptors in the mammalian central nervous system. Prog Neurobiol 54: 581-618, 1998.

2. Bennett MR and Balcar VJ: Forty years of amino acid transmission in the brain. Neurochem Int 35: 269-280, 1999.

3. Pin JP and Acher F: The metabotropic glutamate receptors: structure, activation mechanism and pharmacology. Curr Drug Targets CNS Neurol Disord 1: 297-317, 2002.

4. Parsons CG, Danysz W and Quack G: Glutamate in CNS disorders as a target for drug development: an update. Drug News Perspect 11: 523-569, 1998

5. Niswender CM, Jones CK and Conn PJ: New therapeutic frontiers for metabotropic glutamate receptors. Curr Top Med Chem 5: 847-857, 2005.

6. Gill S and Pulido O (eds). Glutamate Receptors in Peripheral Tissue. Kluwer Academic/Plenum Publishers, New York, 2005.

7. Ikonomidou C, Bosch F, Miksa M, Bittigau P, Vöckler J, Dikranian K, Tenkova TI, Stefovska V, Turski L and Olney JW: Blockade of NMDA receptors and apoptotic neurodegeneration in the developing brain. Science 283: 70-74, 1999.

8. Luján R, Shigemoto R and López-Bendito G: Glutamate and GABA receptor signalling in the developing brain. Neuroscience 130: 576-580, 2005.

9. Rzeski W, Turski L and Ikonomidou C: Glutamate antagonists limit tumor growth. Proc Natl Acad Sci USA 98: 6372-6377, 2001.

10. Haas HS, Pfragner R, Siegl V, Ingolic E, Heintz E and Schauenstein K: Glutamate receptor-mediated effects on growth and morphology of human histiocytic lymphoma cells. Int $\mathrm{J}$ Oncol 27: 867-874, 2005.

11. Choi S-W, Park S-Y, Hong S-P, Pai H, Choi J-Y and Kim S-G: The expression of NMDA receptor 1 is associated with clinicopathological parameters and prognosis in the oral squamous cell carcinoma. J Oral Pathol Med 33: 533-537, 2004.

12. Li S, Huang S and Peng S-B: Overexpression of G proteincoupled receptors in cancer cells: Involvement in tumor progression. Int J Oncol 27: 1329-1339, 2005.
13. Chang HJ, Yoo BC, Lim S-B, Jeong S-Y, Kim WH and Park J-G Metabotropic glutamate receptor 4 expression in colorectal carcinoma and its prognostic significance. Clin Cancer Res 11: 3288-3295, 2005

14. Kalariti N, Lembessis P and Koutsilieris M: Characterization of the glutametergic system in MG-63 osteoblast-like osteosarcoma cells. Anticancer Res 24: 3923-2929, 2004.

15. Pacheco R, Ciruela F, Casadó V, Mallol J, Gallart T, Lluis C and Franco R: Group I metabotropic glutamate receptors mediate a dual role of glutamate in T cell activation. J Biol Chem 279: 33352-33358, 2004.

16. Pollock PM, Cohen-Solal K, Sood R, Namkoong J, Martino JJ, Koganti A, Zhu H, Robbins C, Makalowska I, Shin SS, Marin Y, Roberts KG, Yudt LM, Chen A, Cheng J, Incao A, Pinkett HW, Graham CL, Dunn K, Crespo-Carbone SM, Mackason KR, Ryan KB, Sinsimer D, Goydos J, Reuhl KR, Eckhaus M, Meltzer PS, Pavan WJ, Trent JM and Chen S: Melanoma mouse model implicates metabotropic glutamate signaling in melanocytic neoplasia. Nat Genet 34: 108-112, 2003.

17. Marín YE and Chen S: Involvement of metabotropic glutamate receptor 1 , a $\mathrm{G}$ protein coupled receptor, in melanoma development. J Mol Med 82: 735-749, 2004.

18. Marín YE, Namkoong J, Cohen-Solal K, Shin S-S, Martino JJ, Oka $M$ and Chen S: Stimulation of oncogenic metabotropic glutamate receptor 1 in melanoma cells activates ERK1/2 via PKCepsilon. Cell Signal 18: 1279-1286, 2006.

19. Litschig S, Gasparini F, Rueegg D, Stoehr N, Flor PJ, Vranesic I, Prezeau L, Pin J-P, Thomsen C and Kuhn R: CPCCOEt, a noncompetitive metabotropic glutamate receptor 1 antagonist, inhibits receptor signaling without affecting glutamate binding. Mol Pharmacol 55: 453-461, 1999.

20. Sun W and Schuchter LM: Metastatic melanoma. Curr Treat Options Oncol 2: 193-202, 2001.

21. Bafaloukos D, Aravantinos G, Fountzilas G, Stathopoulos G, Gogas H, Samonis G, Briasoulis E, Mylonakis N, Skarlos DV and Kosmidis P: Docetaxel in combination with dacarbazine in patients with advanced melanoma. Oncology 63: 333-337, 2002.

22. Atallah E and Flaherty L: Treatment of metastatic malignant melanoma. Curr Treat Options Oncol 6: 185-193, 2005.

23. Chawla-Sarkar M, Leaman DW, Jacobs BS and Borden EC: IFN-beta pretreatment sensitizes human melanoma cells to TRAIL/Apo 2 ligand-induced apoptosis. J Immunol 169: 847-855, 2002.

24. Xiang JH and Kimura AK: In vitro modulation of the metastatic phenotype. I. Analysis of differentiation forms of the B16 melanoma expressing Met-72 determinants and metastatic activity. Clin Exp Metastasis 4: 293-309, 1986.

25. Ritzén A, Mathiesen JM and Thomsen C: Molecular pharmacology and therapeutic prospects of metabotropic glutamate receptor allosteric modulators. Basic Clin Pharmacol Toxicol 97: 202-213, 2005.

26. Kew JNC: Positive and negative allosteric modulation of metabotropic glutamate receptors: emerging therapeutic potential. Pharmacol Ther 104: 233-244, 2004.

27. Kohara A, Toya T, Tamura S, Watabiki T, Nagakura Y, Shitaka Y, Hayashibe S, Kawabata S and Okada M: Radioligand binding properties and pharmacological characterization of 6-amino-Ncyclohexyl-N,3-dimethylthiazolo[3,2-a]benzimidazole-2carboxamide (YM-298198), a high-affinity, selective, and noncompetitive antagonist of metabotropic glutamate receptor type 1. J Pharmacol Exp Ther 315: 163-169, 2005.

28. Namkoong J, Martino JJ and Chen S: From existing therapies to novel targets: a current view on melanoma. Front Biosci 11: 2081-2092, 2006. 